\title{
THE RAREST TYPE OF BLUE JAY
}

by Richard G. Conn, Chief, Division of Human History,

Manitoba Museum of Man and Nature, Winnipeg

Look west! Just over the Rockies into interior British Columbia and western Montana you will see a region of rough, broken mountain ridges that begin as foothills east of the Columbia and grow higher and more heavily timbered until they rival the main ranges of the Continental Divide. The swift, clear rivers of the country - the Flathead, Pend Oreille, and Kootenai - punctuate the mountains, drawing off the surplus of winter snow and spring rain, and offering the easiest means of access to the lush valleys. In the fur trader's day and long before, the rivers were the roads: to an Indian trading fair at the Dalles or back home to the fur depots in the Canadas. Even today, the highways and railroads follow the riverbanks through the mountain gorges. The intermontane region is rugged and inaccessible, true, but it is also rich in Nature's bounty. Many a fortune has been coined with the timber from its hills and minerals inside them. Those who prefer not to prey upon their environment find riches of another sort in groves of stately Ponderosas, sparkling mountain lakes, and a wealth of fish and game.

In the valleys of this interior region you might meet men and women of the Salish-speaking Indian tribes whose ancestors settled this area at least four thousand years ago. Looking further among these old settlers, you might find one of the last few living Bluejays-a Salishan man set apart by his dealings with the supernatural and the special skills he has acquired in consequence. Although the true Blue Jay (Cyanocitta cristata) is unknown in the area, this name is commonly applied to Steller's Jay (Cyanocitta stelleri) by the Englishspeaking residents of the intermon. tane region. An English-speaking Salishan would be likely to follow this usage. As applied to an Indian, the name becomes a single word. The Salishan Bluejay shares Cyanocitta's reputation for outrageous and impudent behaviour, but he has gone beyond this to develop his skills in clairvoyance and divination.

To explain the nature of the Bluejay, we have to consider some basic Salishan religious concepts. Like most North American Indians, these people believed in a vast spirit world: sensed rather than seen and existing all about them. The spirit folk controlled forces and conditions humans could only hanker after, such as the weather, movements of game animals, and the laws of chance. So it was obvious that Man had to establish relations with the Unknown to improve his precarious situation. Being a democratic people, the Indians approached the Supernatural as individuals. Boys-and sometimes girlswent out to a solitary vigil in the forests or on a hilltop shortly after reaching puberty. By his courage in facing this test, by the fast he observed, and by the prayers he offered, the novice showed his worthiness and hoped to attract the sympathy of a benevolent spirit who would become his life-long mentor. If the novice's appeal was good enough, a spirit came to him in a vision, taught him a "power" song and told him how to increase magically his skill in some activity - perhaps hunting or gambling. Throughout his life the boy would sing his magic song whenever he needed reassurance and obey any special instructions his $\mathrm{guardian}$ spirit had given him. The Other World would be pleased and the novice's success was assured.

One contact with the Supernatural was enough for most people. They were content with the security and strength a single guardian spirit offered. But in each generation there were a few boys who went much far- 
her. Perhaps the religious life apealed to them, or maybe-as the ndians would see it - the spirits ought them out. In time these excepional young men acquired other upernatural teachers and a growing bility to work with the Unknown. In ime they could even approach the host powerful and dangerous forces tho in their turn might bestow the reatest powers. Most of those who athered such strength became "docors" and devoted themselves to curing oth mental and physical sicknesses. Ine or two, however, encountered the Bluejay spirit and were obliged to lay a different role.

How are we to describe the attriutes and personality of a spirit, then those Indians who know somehing of it are uncertain and usually nwilling to talk? We may infer that he Bluejays' mentor was very powerul, well-nigh impossible to control, nd as capricious as the bird itself. t gave its human protégés ability to ead other people's thoughts, to foreell the future, to find lost things, and ome skill in influencing another's ctions or ideas. At times Bluejays vere asked to treat invalids - gener- ally the hopeless cases - but their services tended to be more personal than practical. One could retain a Bluejay for his clairvoyant skill, to warm up a cold heart, or even to guarantee a horse race.

The most striking expression of the Bluejay spirit came at the mid-winter Guardian Spirit Dances. Anyone with a spirit protector (and this included most of the adult population) could take part. Acting one at a time, men sang their magic songs and danced. The Indians believed that the spirits actually visited the dance to help and inspire their human partners. But the Bluejays, by their spectacular performances, showed the difference between their demanding teachers and the gentler supernatural patrons of other men. The Bluejay spirit did not simply inspire its bearer; it possessed him suddenly and dramatically. The Bluejay men began to chatter wildly in unintelligible language and rushed erratically around the dance lodge. Anthropologists use the expression "contrary behaviour" to describe a further part of his conduct. If a Bluejay were still speaking intelligible Salish and announced his intention of

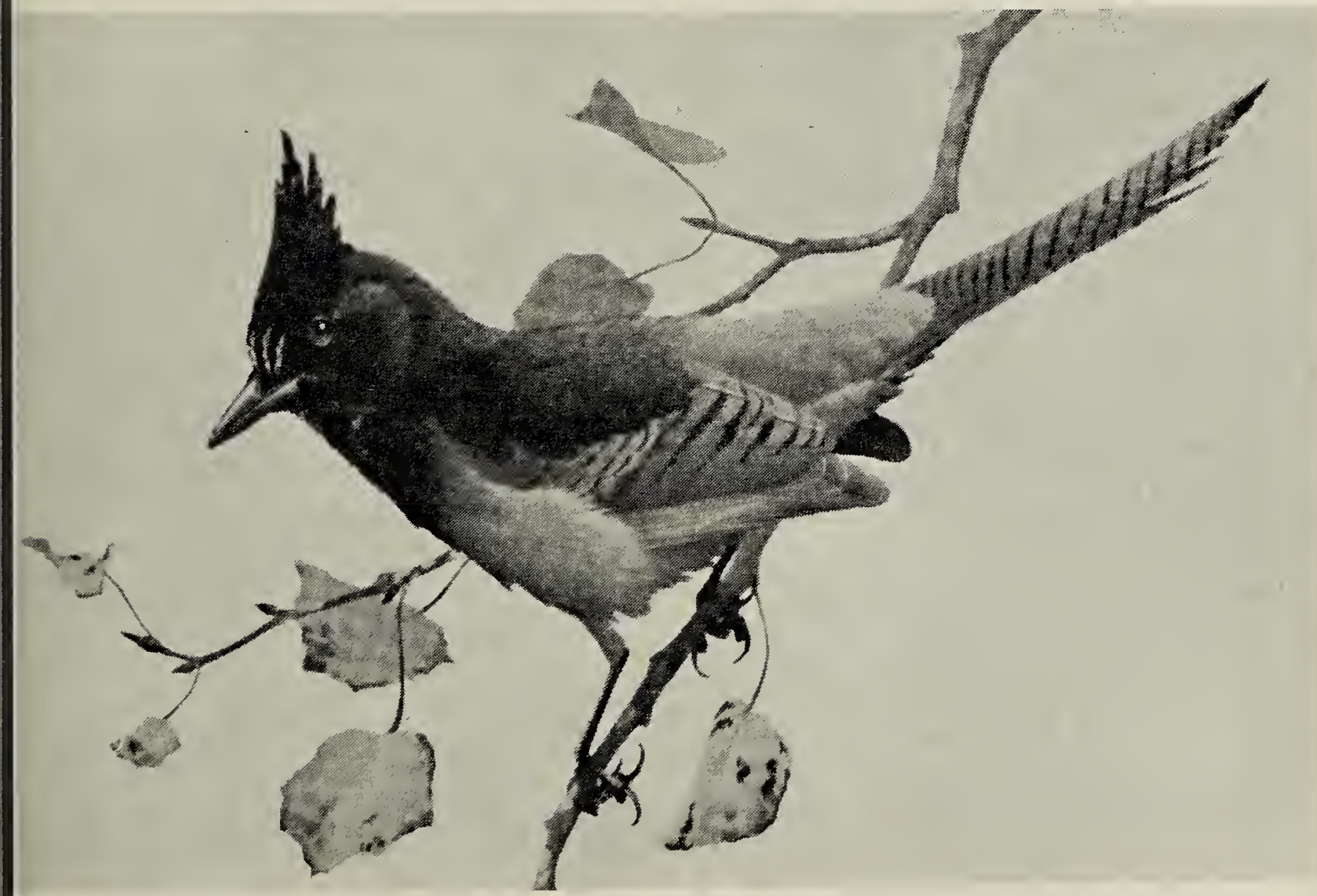

teller's Jay

from a painting by F. Lansdowne 
doing something he immediately did the exact opposite. If any spectator asked him to do something, he did the reverse of this as well. Sometimes anxious dance leaders took advantage of the situation by shouting "don't stand still" in order to quiet a frenzied Bluejay. In their possessed state the Bluejays could also read the secret thoughts of anyone present and would spew them out with no regard for the consequences. This uncanny ability gave the spectators a chance to practise mental discipline. Some years ago the writer heard a Salish woman laughing at her efforts to avoid thinking about an intimate family problem as a Bluejay was dancing.

Not content with wreaking social chaos, the spirit demanded athletic feats as well. It is said that formerly Bluejay dancers climbed out the dance lodge's smoke channel and clambered about on the ridge poles. Considering the light construction of an old-style dance lodge, this would have been a truly dare-devil performance. In addition, the Bluejays are said to have climbed trees near the lodge where they sat perched, screaming like jays and waving their arms, until the other dancers could coax them down. Today, when the few living Bluejays are elderly men, these violent parts of the dancing are no longer practised.

If we can say little about the Bluejay spirit, we can only guess why it came to be associated with the bird. A possible hint toward the answer may lie in Salishan mythology. Like so many other people, the tribes told stories of an earlier time when men and animals lived on equal footing and spoke a common language. Consequently, Salishan myths have many animal characters. Each of these has a rudimentary personality, based perhaps on human-like traits manifested by the actual species, and elaborated in direct proportion to its importance in the body of legend. Considering that the story-tellers were looking for human analogies in animal behaviour, we can almost predict the stereotypes some myth-animals will assume: the wolf is a hardy hunter, the eagle a brave warrior, and so on. When an animal didn't display behavioural patterns similar to human motivations, the Indian story-teller used his imagination freely. Thus the meadowlark appears in one story as a naïve, lovable little person much like Pogo the Possum. Stranger yet, the Blacktail doe is cast as a voluptuous siren. The Bluejay appears in Salishan legends as an impudent, aggressive upstart. This portrait was very likely drawn from observation of actual Steller's Jays with a liberal portion of imagination added. If this can be taken as the Salishan opinion of the bird, we may consider it a clue to the relationship we seek. Let us ask cautiously-for we are on speculative ground now - whether the Salishan people saw similarities between the bird's rambunctious ways and the actions of dancers possessed by the spirit. If this was so, we might ask further if the Indians imagined that the behaviour of both human and avian Bluejays was directed by the same supernatural agency. But this is all conjecture, for the knowledge available to us simply will not answer the question completely. Some of the possessed dancers' conduct - in particular, perching in trees and screaming like birds-suggests a kind of imitation and implies that the coincidence of names is not accidental. We may guess, then, that the Bluejay dancer and his tutelary spirit are somehow associated in the Indian view with the bird, but we cannot be sure how.

Why did men become Bluejays? Certainly not for gain or profit, for their services were so specialized that they must have had few clients. Perhaps for prestige, since they had their share of this commodity. But the Bluejays, if respected, were regarded with awe and even fear because their skills could be turned to malevolent ends. The poor Bluejay's magical abilities may have brought him fame, but they also set him apart from his fellows. In the Indian view, men didn't seek the Bluejay power-it came for them. Being a Bluejay in a Salishan camp may have been something like being 
suspected saint in Mediaeval Europe: ringing few earthly rewards, respect mingled with fear and even hostility, and a slight estrangement from humanity.

Today there are only a handful of Bluejays. With the decline of the old Indian religion, there may be no more. The living Bluejays are elderly and unable to take an active role in the midwinter dances. Although they no longer climb the rafters, they still command respect. Christian Indians and even white homesteaders on the Salish reservations are sometimes uneasy in their presence, and most of the Salish tribesmen react to them with wary deference.

In the summer of 1953, a young Indian man disappeared from his nome on the Colville Reservation in horth central Washington State. When neither the reservation police nor the state patrol could find him, the family sent to Montana for a Bluejay. This man came at once to the family home and held a shamanistic seance in which he described both the secret grave and the murderer. His words were not straightforward and direct. Rather his oracle sounded ike the ambiguous remarks of the Delphic priestess or Macbeth's witches. Shortly afterwards, though, the body was recovered in a place fitting the Bluejay's description and the terrified murderer confessed.

Naturally the seance was a closed affair with few people outside the family invited. However, a day or so later I had a brief glimpse of this man who had the entire Reservation buzzing. On his way back to Montana, his car stopped for gas and the station attendant-a young white man-took the old man a glass of water. He wore a black ten-gallon hat with a blue silk scarf tied around the crown and his iron-grey braids were neatly wrapped in fur. He looked frail and tired, but his eyes twinkled as he smiled and returned the empty glass. I have seen him several times since walking along the streets of the little reservation towns with his cane and big hat. It is sad to think there may be no more like him, for even the Twentieth Century has a place for this-the rarest of Blue Jays.

Readers wanting more information about the Bluejays of the Salishan tribes are referred to the following two papers:

Ray, Vern F. 1937. The Bluejay character in the Plateau Spirit Dance. American Anthropologist, new series, $39: 593-601$.

Turney-High, Harry H. 1933. The Bluejay Dance. American Anthropologist, new series, $35: 103-7$.

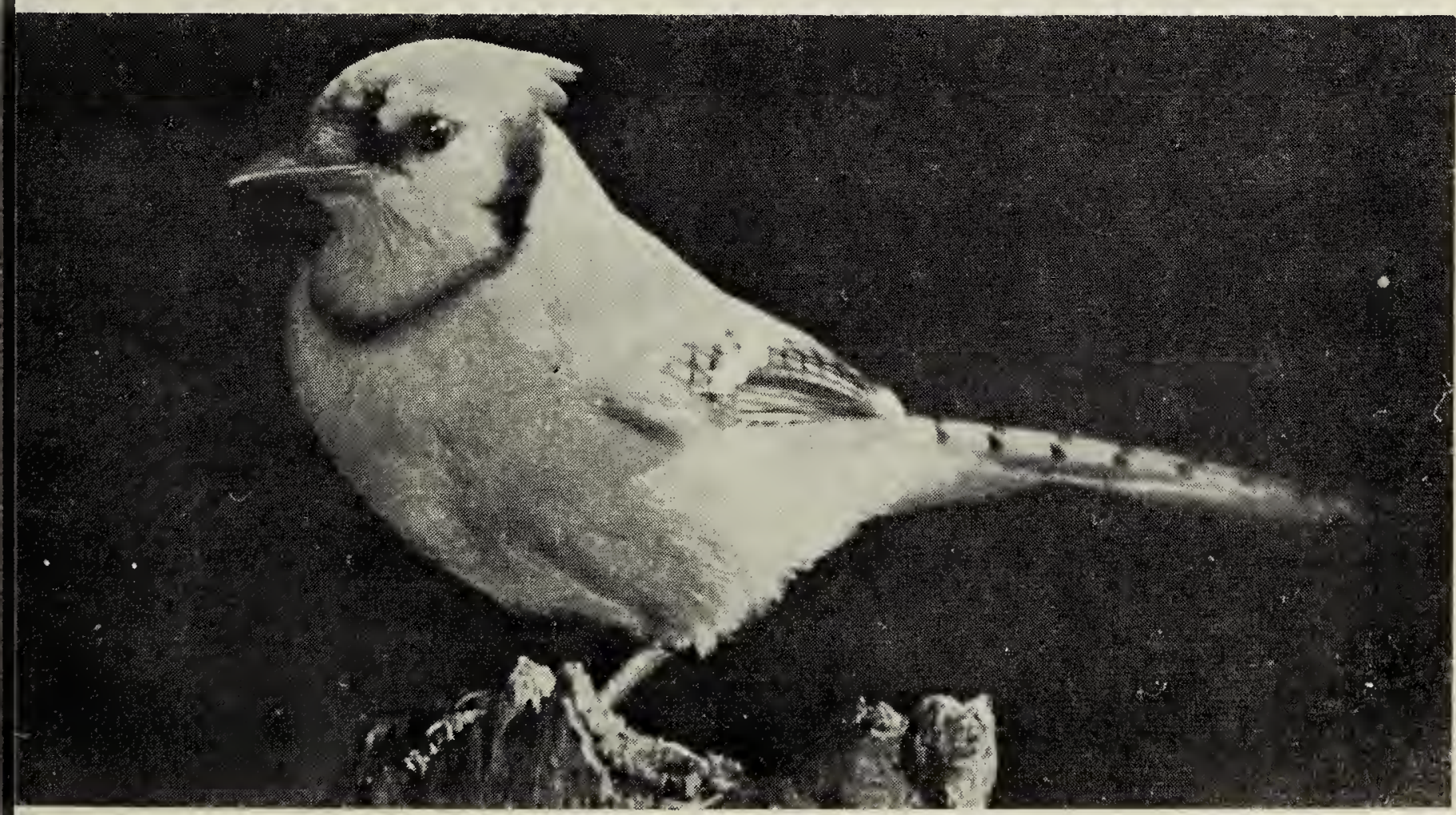

